\title{
Misconceptions on The Concept of Mediation and Conciliation in The Act on Industrial Relations Disputes Settlement
}

\author{
Mohammad Zamroni ${ }^{1}$ \\ ${ }^{1}$ Faculty of Law, Universitas Hang Tuah Surabaya \\ Corresponding author's email: zamroni@hangtuah.ac.id
}

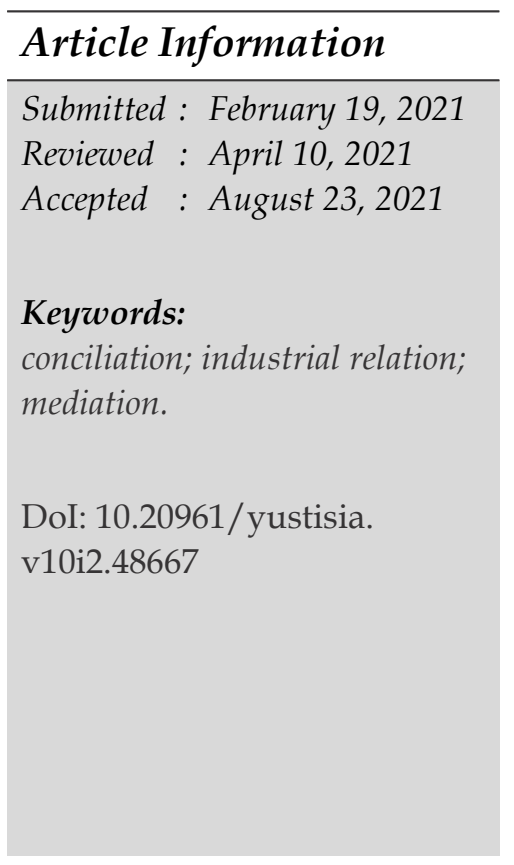

\begin{abstract}
Mediation and conciliation are alternatives with varying characteristics acting as a third-party figure in settling disputes in industrial relations. These alternatives are perceived as the same in Act Number 2 of 2004 on Industrial Relations Disputes Settlement. It leads to conceptual errors and causes mistakes in formulating the mediator and conciliator's authority. Therefore, this study analyzed the concepts of mediation and conciliation as regulated in Act Number 2 of 2004 on Industrial Relations Disputes Settlement. This is a normative legal research carried out with the statutory, conceptual, and comparative law approaches. The result showed that the concept of mediation and conciliation formulated in the Act Number 2 of 2004 on Industrial Relations Disputes Settlement deviates from the basic concepts of the mediator and conciliator to make written recommendations. Conceptually, the mediator and conciliator are facilitators incapable and capable of making written recommendations, respectively.
\end{abstract}

\section{Introduction}

Disputes in industrial relations occur due to differences in opinion and interpretation or unfulfilled predetermined rights and obligations, either based on collective agreement or the basis of statutory regulations. These differences are usually resolved with the terms used in the resolution mechanism specifically regulated in Act Number 2 of 2004 on Industrial Relations Disputes Settlement.

This regulation is a lex specialist for dispute settlement. It systematically regulates the resolution mechanism of the dispute that occurred in industrial relations. Act Number 2 of 2004 on Industrial Relations Disputes Settlement is more open, mainly because it accommodates alternative family settlement, unlike Act Number 22 of 1957. The existence of mediation and conciliation institutions needs to be highly appreciated,

\begin{tabular}{l|ll}
\hline 240 & Yustisia Volume 10 Number 2 (May-August 2021) $\quad$ Misconceptions on The Concept of...
\end{tabular}


although it occasionally leads to misconceptions on the formulation of its authority, which occurs for several reasons. It is due to the lack of references in Act Number 2 of 2004 on Industrial Relations Disputes Settlement or the fallacy associated with understanding the mediation and conciliation concepts.

Generally, these are 2 different terms, and apart from being alternative dispute resolution institutions asides from the court, they both serve as a third party or mediator. In these institutions, the mediator and conciliator submit the disputing parties' final result. Therefore, it is natural to assume that mediation and conciliation are alternative institutions for similar dispute resolution (Black, 2009). However, they are dissimilar because each has different characteristics and is regulated by most positive laws, for example, the French Code of Civil Procedure and that of Indonesia.

According to Brandon and Stodulka, a mediator is a passive intervention actor. Generally, it helps the disputing parties to communicate with each other to identify, clarify, and explore the problem together. An agreement is reached based on the autonomy principle. Meanwhile, the conciliator is an active interventionist and plays an advisory role in the dispute resolution process. Apart from making certain suggestions, they also adopt intervention techniques that actively influence the agreement's outcome and encourage the parties to resolve their disputes. (Brandon \& Stodulka, 2008)

Relying on Brandon and Stodulka's opinions, the mediator and conciliator play different roles in the dispute resolution process. The mediator is passive, while the conciliator and the involved parties actively finds a solution. On the contrary, Act Number 2 of 2004 on Industrial Relations Disputes Settlement does not differentiate the roles of mediator and conciliator, besides they have similar powers. It was clearly stated in the provisions of Article 1 points 12 and 14, both the mediator and the conciliator are authorized to provide written recommendations to the disputing parties. Furthermore, Articles 13 and 23, paragraph (2) stated that the mediator and conciliator issue a written recommendation supposing no agreement was reached.

The Constitutional Court even strengthened its authority to submit written recommendations to the disputing parties as formulated in Act Number 2 of 2004 on Industrial Relations Disputes Settlement through Decision No. 68/PUU-XIII/2015. Irrespective of the fact that the verdict is corrective to the meaning of the phrase "written recommendation," the Constitutional Court's perception of the mediator and conciliator's authority is similar to Act Number 2 of 2004 on Industrial Relations Disputes Settlement. The Constitutional Court also believes that each of them needs to issue written recommendations.

A different opinion was expressed by the Ministry of Manpower Team regarding its evaluation of Act Number 2 of 2004 on Industrial Relations Disputes Settlement. Based on the analysis and evaluation, it was concluded that the people behind this regulation do not understand the basic principles of alternative dispute resolution. Sunarno (2011) stated that a win-win solution is the main focus, not a zero-sum game. In law, mediation institutions do not recognize recommendations because mediators are only facilitators 
and are thereby perceived as passive. All solutions to problems depending on the disputing parties, not the mediator that only offers a bit of advice. (Sunarno, 2011)

Based on the earlier mentioned description, it is necessary to carry out a study on mediation and conciliation as regulated in Act Number 2 of 2004 on Industrial Relations Disputes Settlement. The research aims to determine the basic concept of mediation and conciliation.

\section{Research Method}

This is a normative legal research aimed to analyze the basic concepts of mediation and conciliation stipulated in the Act of PPHI. The statutory, conceptual, and comparative law approaches were used to carry out this research. Meanwhile, the legal materials used were mainly acts and scientific papers such as books, journals, articles, etc. In addition, both soft-copy and hard-copy were systematically compiled and analyzed using the aforementioned approaches. The results were summarized, and the concluding aspect is the answer to this study's legal issue.

\section{Basic Concept of Mediation and Conciliation}

\section{A. Basic Concept of Mediation}

The term "mediation" is derived from the Latin word "medicare" which means "to meditate" or "be in the middle" (McDowell, 2017). "Medicare" implies a third party's existence and role as an intermediary between 2 parties. McDowell stated that initially, mediation was commonly used to connect humans and the divine (God), and a typical example is Christ (Bible Society, n.d.).

According to the Black's Law Dictionary, mediation is a non-binding method of dispute resolution involving a neutral third party that tries to help the parties reach a mutually agreed solution (Black, 2009). The Major Indonesia Dictionary (KBBI) describes it as a process involving a third party or advisor to resolve a dispute (Badan Pengembangan and Pembinaan Bahasa, n.d.-b). The USLegal Dictionary defines mediation as a non-contradictory alternative method of dispute resolution, where a neutral third party helps resolve disputes (USLegal, n.d.-b). The Oxford English Dictionary describes this term as the process of resolving non-litigation disputes through negotiation with neutral intermediaries (Oxford English Dictionary, n.d.).

The United Nations describes mediation as a process whereby a third party helps to either prevent, control, or resolve conflicts by developing a mutual understanding(United Nations, 2012). Ireland's Law Reform Commission (LRC) defined mediation as a facilitative, structured, and confidential process where those involved attempt to voluntarily reach a mutual agreement to resolve disputes with the help of an independent third party called a mediator (Law Reform Commission, 2010). Australia's National Alternative Dispute Resolution Advisory Council (NADRAC) stated that mediation is a process whereby a dispute resolution practitioner (mediator) assists the parties to identify disputed 
issues, develop options, consider alternatives, and seek to reach an agreement (NADRAC, 2011).

This term has also been used in Indonesian acts and regulations since 1999. However, not all policies provide a clear definition. In accordance with Article 89 (4) letter b of Act Number 39 of 1999 on Human Rights, mediation is the settlement of civil cases outside the court based on agreement. Conversely, Act Number 30 of 1999 on Arbitration and Alternative Dispute Resolution stated that mediation is an alternative to dispute resolution.

Article 1 point 11 of Act Number 2 of 2004 on Industrial Relations Disputes Settlement states that mediation is the resolution of disputes over ones' rights, interests, employment termination, and disagreement between trade and labor unions in a company through deliberations mediated by one or more neutral mediators.

The formulation of article 1 point 11 of Act Number 2 of 2004 on Industrial Relations Disputes Settlement failed to provide a precise meaning. It only stated several types of industrial relations disputes cumulatively using the conjunction 'and, although this certainly creates ambiguity.

Different definitions are formulated in the Supreme Court Regulation of the Republic of Indonesia Number 1 of 2016 on Mediation Procedures in Courts (PERMA Mediation). Article 1 point 1 PERMA Mediation described it as a method of dispute resolution through a negotiation process to reach an agreement with the assistance of a mediator. The formula is relatively straightforward, therefore it does not cause any ambiguity.

Based on the aforementioned definitions, mediation is presumed to resolve disputes through deliberation based on mutual agreement facilitated by the mediator. The phrase "based on mutual agreement" refers to the entire resolution process, starting from a mediator's appointment to determining the mediation procedure and the outcome. Therefore, the mediator's role is no more than a facilitator whose function is to bridge the interests of the disputing parties.

According to McDowell (2017), mediation is a process or phenomenon which connects 2 entities through media. Therefore, an intermediary such as a mediator is required. Black's Law Dictionary defines it as a neutral person that seeks to help the disputing parties reach an agreement (Black, 2009). The Major Indonesia Dictionary (KBBI) describes a mediator as an intermediary (liaison) (Badan Pengembangan dan Pembinaan Bahasa, n.d.-c). The Oxford English Dictionary defines this term as someone that intervenes between 2 parties to resolve disputes through mediation (Dictionary, n.d.).

A mediator facilitates communication, helps the parties reach a mutually satisfying agreement, and is not authorized to make decisions or enforce an outcome (USLegal, n.d.-b). According to NADRAC, they do not have an advisory or determinant role on the disputed material or the resolution however, they are able to offer advice or determine the mediation process (NADRAC, 2011). Wall 
and Lynn (2017) described the mediator as a third party in charge of interactions, although it has little control over the outcome.

The mediator's role is no more than a facilitator (Lockwood et al., 2010) because all mediation processes are carried out based on the parties' agreement. Besides, their primary function is to ensure that the negotiation process continues following the parties' agreement, thereby causing them does to interfere. Based on the JAMS mediator code of ethics, the mediator needs to refrain from giving legal advice (JAMS Mediation Services, n.d.). Likewise, the Initiative Mediation Support Deutschland (IMSD) emphasizes on the fact that they need to refrain from making substantial recommendations or suggestions (Federal Foreign Office \& Initiative Mediation Support Deutschland, 2017). It is in line with the Irish LRC's opinion, which states that the mediator need not advise the parties to resolve their dispute (Law Reform Commission, 2010).

The International Labor Organization (ILO) believes that the mediation's conceptual purpose is to facilitate dialog between the parties involved in a dispute. Meanwhile, a mediator is mainly responsible for promoting the negotiation process (ILO Jakarta, 2006). They need to possess the following qualities honesty, integrity, neutrality, and competence (ILO Jakarta, 2006). The mediator is not a judge that needs legal facts or evidence to arrive at a decision. In this case, possessing excellent mediation competence is essential. Mediation is a dispute resolution based on the parties' interests (Law Reform Commission, 2010).

Based on the aforementioned implications, the mediators do not need to be experts in areas of disputes. Additionally, they do not need to provide suggestions or opinions on the subject matter. For example, in cases involving medical disputes, the mediator does not necessarily need to understand this field, likewise that of industrial relations. The fundamental competence is intermediation, which becomes a neutral and impartial intermediary for parties whose civil relations are deteriorating. Therefore, the mediator has to possess the ability to effectively facilitate communication between the parties, which eventually leads to reconciling their differences.

\section{B. Basic Concept of Conciliation}

The word conciliation is an English term, absorbed from the Latin word "conciliare," meaning "unite" (Zlatanska \& Fawehinmi, 2016). Meanwhile, conciliate means reuniting the disputing parties or regaining support or friendship by ending the dispute (Orji, 2012). According to Faget, conciliation is defined based on its purpose (conciliare meaning to reunite). It is different from mediation, which is defined based on the method (mediare meaning being in the middle) (Faget, 2004).

Conciliation is the process of settling disputes with a neutral third party called a conciliator (Mitra, 2018). Black's Law Dictionary described it as a process 
where neutral parties meet with disputing ones to explore ways of resolving the issues (Black, 2009). The Major Indonesia Dictionary (KBBI) defines this term as an attempt to reconcile and resolve the disputing parties' wishes by reaching an agreement (Badan Pengembangan dan Pembinaan Bahasa, n.d.-a). The USLegal Dictionary defines conciliation as the act of resolving disputes amicably outside of the court (USLegal, n.d.-a).

The UNCITRAL Conciliation Rule 1980 reported a peaceful dispute resolution method (UNCITRAL, 1983). The Irish LRC defined conciliation as an advisory, structured and confidential process. An independent third party, called a conciliator, actively assists the parties in voluntarily resolving disputes (Law Reform Commission, 2010). According to NADRAC, it is a process whereby parties, with the help of a dispute resolution practitioner (the conciliator), identify the issue, develop options, consider alternatives and work to reach an agreement (NADRAC, 2011).

Based on this definition, conciliation is a dispute resolution and reconciliation method through deliberation based on mutual agreement achieved with the conciliator's assistance. Generally, this is in line with the definition of mediation. However, there are fundamental differences associated with the role of third parties as intermediaries. In contrast to the mediator's limited role as a facilitator, the conciliator is more active in seeking solutions by providing options, which are essential. In addition to being made by a neutral and impartial third party, it is also based on their ability to understand the cause of the dispute. Therefore, it is expected that the parties accept the conciliator's options, which leads to reconciliation. NADRAC (2011) further explained that the conciliator addresses disputed matters and provides options for resolution.

According to Zlatanska and Fawehinmi (2016), their role is to clarify the issues and provide recommendations for solutions. It is supported by the Irish LRC's opinion, which stated that the conciliator makes a dispute resolution proposal to the parties at any stage in the conciliation process, irrespective of the fact that it need not be accepted (Law Reform Commission, 2010). This role itself has certain consequences therefore, the conciliator has to be an expert in the area related to the dispute (NADRAC, 2011). The conciliator acts as an intermediary and needs to be able to proffer solutions or options to the disputed problem. Their expertise is considered to be extremely important, therefore, the American International Center for Settlement of Investment Disputes (ICSID) stipulated certain requirements that need to be possessed by a conciliator, including being competent in the fields of law, trade, and the finance industry (See the provisions of Article 14 of the Convention on The Settlement of Investment Disputes Between States and Nationals of Other States 2006).

In Article 67 (4) of The Arbitration and Conciliation Act, Year 1996, India, which refers to the provisions of Article 7 (4) of the 1980 UNCITRAL Conciliation Rules, stated that the conciliator makes proposals to resolve disputes at every stage. These proposals do not have to be written or supported by reasons. 
However, when this matter is associated with labor disputes, Sazeeda stated that the conciliator proffers a solution to reach an agreement between workers and companies. However, they need not force the solution because the decision is the disputing parties' right (Thakur, 2018).

Meanwhile, in Japan, conciliation is carried out outside the court, although it is included in the litigation process (Funken, 2005). The conciliation institution in Japan is called Chotei and is used to settle small claims since the establishment of the Summary Court after the Second World War (Barnes, 2007). A conciliator mediates conciliation during the litigation process called the Chotei Commission. This consists of a judge regarded as the chairman and 1 or 2 Conciliation Commissioners from private conciliators (Civil Conciliators). These are generally professional lawyers with not less than 5 years of practicing experience, and they are appointed by the Supreme Court (Kusano, 2008). Australia NADRAC defines conciliation as a process whereby parties, with the help of a dispute resolution practitioner (the conciliator), identify the issue, develop options, consider alternatives and work to reach an agreement.

In the conciliation process, the Chotei Committee examines the people or places related to the dispute's subject, including summoning witnesses and experts. The committee is also able to prohibit parties from engaging in activities, which leads to some difficulties in terms of reaching a settlement (Funken, 2005). The conciliation provisions in Japan are more or less similar to that of India. It gives the conciliator the authority to request and examine evidence related to the subject of the dispute (See the provisions of Article 71 of The Arbitration and Conciliation Act 1996 India).

Based on earlier mentioned implications, asides from being an intermediation expert, a conciliator also needs to be experienced in the dispute's subject matter, or adequately understand the issues. This expertise is vital because they are the facilitators of the disputing parties and need to be able to provide suggestions, opinions, or potential settlement options. The primary role of the conciliator is to help the parties reconcile. In the end, the relationship between the parties returns to the way it was before the dispute.

\section{Mediation and Conciliation in the French Code of Civil Procedure}

Mediation and conciliation procedures are sufficiently regulated in the French Code of Civil Procedure. It starts from the time of implementation, their authorities, and an independent mediator's requirements. Although the mediation and conciliation procedures are relatively similar, some fundamental differences are particularly concerned with their powers.

The duration of the mediation process need not exceed 3 months. However, the mediator is authorized to apply for an extension of another 3 months (Articles 131-3). Meanwhile, the conciliation process lasts for a maximum of 1 month and was extended for another 1 month (Article 832).

246 Yustisia Volume 10 Number 2 (May-August 2021)

Misconceptions on The Concept of... 
The mediator is not authorized to direct the parties or appointed to examine the same process. However, with the consent of those involved and mediation purposes, the mediator tends to listen to the third party (Articles 131-8). Meanwhile, the conciliator performs a local inspection. The mediator also listens to the testimonies of those that are useful, with the agreement of the parties (Article 832-4). However, all conciliator's findings and deleted statements are only used during proceedings based on the consent of the parties (Articles 8329).

Regarding the requirements to become one of these intermediaries, the French Code of Civil Procedure explicitly regulates individual mediators. However, conciliators and mediators from associations are not specifically regulated. Individual mediators have to meet the following requirements (Articles 131-5):

1. They need not be sentenced to any crime.

2. They need not commit acts contrary to honor, honesty, and order, which results in disciplinary or administrative sanctions.

3. Have experience and qualifications in carrying out mediation processes related to disputes.

4. Have evidence of training or experience in mediation.

5. Able to demonstrate the independent capacity required in mediation.

\section{Mediation and Conciliation in the Act Number 2 of 2004}

Conceptually, Act Number 2 of 2004 on Industrial Relations Disputes Settlement perceives mediation and conciliation as being similar. The formulation of Articles 11 and 21 of Act Number 2 of 2004 on Industrial Relations Disputes Settlement gives mediators and conciliators equal authority in summoning witnesses or experts to attend the mediation hearing, testimonies, including opening the necessary books and letters. Likewise, the formulation of Article 13 and 23 (2) of Act Number 2 of 2004 on Industrial Relations Disputes Settlement gives equal authority to mediators and conciliators to issue written recommendations, assuming no agreement was reached during the mediation conciliation process.

The Constitutional Court even followed the perception of Act Number 2 of 2004 on Industrial Relations Disputes Settlement on mediation and conciliation concepts, as described in decision Number 68-PUU-XIII-2015. According to the Constitutional Court, written recommendations are part of the settlement's minutes realized through mediation and conciliation. Therefore, the norms of Articles 13 and 23 paragraphs (2) letter a each of the Act Number 2 of 2004 on Industrial Relations Disputes Settlement needs to be interpreted "in cases, where no agreement has been reached on the settlement of industrial relation disputes resolutions, the mediator or conciliator issues a written recommendation in the form of a treatise. “ 
The Constitutional Court only added the phrase "inform" in the formulation of Articles 13 and 23 paragraphs (2) letter a of the Act Number 2 of 2004 on Industrial Relations Disputes Settlement. It simply means that the court's perception of the conciliator and mediator's authority in terms of written recommendations is similar to Act Number 2 of 2004 on Industrial Relations Disputes Settlement. Conversely, the application substance for the judicial review against the norms of Articles 13 and 23 paragraphs (2) letter a of Act Number 2 of 2004 on Industrial Relations Disputes Settlement is based on the mediator and conciliator's authority to issue unregulated minutes of settlement through mediation and conciliation processes.

The Constitutional Court needs to interpret the norms of Articles 13 and 23 paragraphs (2) letter a based on the basic concepts of mediation and conciliation, each of which has different characteristics. Since conceptually the mediator is not authorized to make a written recommendation, the norm of Article 13 paragraph (2) letter a is interpreted, "in cases where no agreement was reached on the settlement of industrial relation dispute resolution through mediation, the mediator issues a treaty." In other words, the mediator is only authorized to issue the settlement's minutes rather than written recommendations.

The perception of Act Number 2 of 2004 on Industrial Relations Disputes Settlement that equates to the mediation and conciliation concepts certainly deviates from the basis. This is due to the different characteristics reported by Zlatanska and Fawehinmi (2016).

1. Mediation is derived from the word mediare, which means being in the middle, while conciliation is obtained from the term conciliare, which implies unity. Although maintaining the relationship between the parties is essential, mediation frequently resolves disputes without reconciliation. Meanwhile, conciliation always improves the relationship between the disputing parties.

2. In general, mediation is applied when the dispute has become serious and difficult to resolve. Conciliation, on the other hand, is regularly used as soon as a misunderstanding arises. It is more preventive in nature by trying to prohibit and stop conflicts.

3. Although both are informal, the mediation process stages are more structured, while the conciliation steps are more flexible depending on the case.

4. Lawyers are usually active in the mediation process. They proffer solutions to the parties. Meanwhile, in the conciliation process, they only offer advice on the conciliator's proposal.

5. The parties formulate norms according to the agreement in the mediation process, as long as it does not conflict with the applicable law. Meanwhile, the agreement is generally influenced by the norms stipulated in the applicable law in the conciliation process. 
6. The most fundamental difference is the level of third-party intervention. The mediator only helps the parties to reach an agreement made by themselves. They are also responsible for the settlement process and not the resolution. On the contrary, the conciliator is accountable for evaluating existing problems and trying to create suitable solutions.

According to Brandon and Stodulka, conciliators are active interveners and play an advisory role in the outcome of the agreement. Meanwhile, the mediator only facilitates the parties to make a mutual agreement (Brandon \& Stodulka, 2008). This is in line with the French Code of Civil Procedure provisions in Articles 131-8, which states that the mediator is not authorized to direct the parties and conduct examinations. Meanwhile, based on Article 832-4, the conciliator conducts local examinations and listens to testimonies based on the party's agreement.

The difference between mediation and conciliation formulated in Act Number 2 of 2004 on Industrial Relations Disputes Settlement is also unclear. They are distinguished based on the type of dispute and the mediator or conciliator. Apart from not having a conceptual basis, the dissimilarities between these 2 are also unclear. Act Number 2 of 2004 on Industrial Relations Disputes Settlement formulated mediation and conciliation procedures to show that there are 2 alternative procedures for resolving this type of dispute, even though they have similar essence.

\section{Conclusion}

In conclusion, the concept of mediation and conciliation formulated in Act Number 2 of 2004 on Industrial Relations Disputes Settlement deviates from the basis by providing the same authority in written recommendations. Conceptually, mediators are facilitators, although they are unable to formulate solutions or issue written recommendations to the parties related to the dispute. Conversely, the conciliator formulates resolution options or issues written recommendations to the parties regarding the dispute.

The concept of mediation and conciliation formulated in the Act of PPHI needs to be adjusted to the basic concepts to clarify the difference. These variations do not need to be distinguished based on the type of case and the mediator or conciliator. Instead, it is based on their authority, which facilitates and makes recommendations.

\section{BIBLIOGRAPHY:}

A. Wall, J., \& Lynn, A. (2017). Mediation: A Current Review. The Journal of Conflict Resolution, 37(1), 160-194.

Badan Pengembangan dan Pembinaan Bahasa. (n.d.-a). Konsiliasi. Retrieved July 22, 2020, from https:/ / kbbi.kemdikbud.go.id/entri/Konsiliasi/

Badan Pengembangan dan Pembinaan Bahasa. (n.d.-b). Mediasi. Retrieved July 19, 2020, from https:/ / kbbi.kemdikbud.go.id/entri/mediasi 
Badan Pengembangan dan Pembinaan Bahasa. (n.d.-c). Mediator. Retrieved July 20, 2020, from https:/ / kbbi.kemdikbud.go.id/entri/mediator/

Barnes, B. E. (2007). Culture, Conflict, and Mediation in the Asian Pacific. University Press of America.

Bible Society. (n.d.). Timothy 2.5. Retrieved July 20, 2020, from https://www.biblesociety. org.uk/explore-the-bible/read/eng/KJV/1Tim/2/5/

Black, H. C. (2009). Black's Law Dictionary (B. A. Garner (ed.); Ninth Edit). Thomson Reuters.

Brandon, M., \& Stodulka, T. (2008). A Comparative Analysis of the Practice of Mediation and Conciliation in Family Dispute Resolution in Australia: How Practitioners Practice across both Processes. QUT Law Review, 8(1), 194-212. https://doi. org/10.5204/qutlr.v8i1.106

Dictionary, O. E. (n.d.). Mediator. Retrieved July 20, 2020, from https://www.oed.com/ view/Entry/115670?redirectedFrom=mediator\#eid

Faget, J. (2004). Mediation and Domestic Violence. Open Edition Journals, I(Varia). https://doi.org/https:// doi.org/10.4000/champpenal.356

Federal Foreign Office \& Initiative Mediation Support Deutschland. (2017). Basics of Meditation: Concepts and Definitions (Issue Fact Sheet Series: Peace Mediation and Mediation Support). Königsdruck.

Funken, K. (2005). Alternative Dispute Resolution in Japan. SSRN Electronic Journal, 1-33. https:// doi.org/10.2139/ssrn. 458001

ILO Jakarta. (2006). Manual Mediasi, Konsiliasi, Arbitrasi. ILO Publications.

JAMS Mediation Services. (n.d.). Mediation Ethics Guidelines. Retrieved July 21, 2020, from https://www.jamsadr.com/mediators-ethics/

Kusano, Y. (2008). Wakai: Terobosan Baru Penyelesaian Sengketa. Grafindo.

Law Reform Commission. (2010). Alternative dispute resolution: mediation and conciliation. Law Reform Commission Ireland, 1-247.

Lockwood, C. M., DeFrancesco, C. A., Elliot, D. L., Beresford, S. A. A., \& Toobert, D. J. (2010). Mediation Analyses: Applications in Nutrition Research and Reading the Literature. Journal of the American Dietetic Association, 110(5), 753-762.

McDowell, P. (2017). Media and Mediation in the Eighteenth Century. Oxford Handbooks Online, November, 1-22.

Mitra, S. B. (2018). Isn't conciliation a best alternative! International Journal of Law, 4(6), $1-5$.

NADRAC. (2011). Glossary of ADR Terms (pp. 1-14). NADRAC Australia. https:// treasury.gov.au/sites/default/files/2019-03/NADRAC.pdf 
Orji, U. J. (2012). Law and Practice of Conciliation in Nigeria. Journal of African Law, 56(1), 87-108. https://doi.org/https://doi.org/10.1017/S0021855311000246

Oxford English Dictionary. (n.d.). Mediation. Retrieved July 20, 2020, from https:/ / www. oed.com/view/Entry/115665?redirectedFrom=mediation\#eid

Sunarno. (2011). Analisis dan Evaluasi Terhadap UU No. 2 Tahun 2004 tentang Penyelesaian Perselisihan Hubungan Industrial. Kementerian Hukum Dan HAM RI, $1-58$.

Thakur, S. J. (2018). Conciliation and Arbitration: Dispute Resolution Mechanism in Bangladesh's Industry. E-Journal of International and Comparative Labour Studies, 7(3), 143-152.

UNCITRAL. (1983). UNCITRAL Conciliation Rule 1980. General Assembly, 297-301. https:// doi.org/10.1016/b978-0-444-86236-5.50084-5

United Nations. (2012). United Nations Guidance for Effective Mediation. United Nations, New York, 1-23. https://peacemaker.un.org/sites/peacemaker.un.org/ files/GuidanceEffectiveMediation_UNDPA2012\%28english\%29_0.pdf

USLegal. (n.d.-a). Conciliation. Retrieved July 25, 2020, from https://definitions.uslegal. $\mathrm{com} / \mathrm{c} /$ conciliation/

USLegal. (n.d.-b). Mediation. Retrieved July 20, 2020, from https:// definitions.uslegal. $\mathrm{com} / \mathrm{m} /$ mediation/

Zlatanska, E., \& Fawehinmi, F. (2016). Mediation and Conciliation : In Pursuit of Clarity. The International Journal of Arbitration, Mediation and Dispute Management, 82(2), 146-152. 